\title{
NZ's Pharmac negotiates deal for Roche's monoclonal antibodies for COVID-19
}

New Zealand's Pharmaceutical Management Agency (Pharmac) has negotiated a deal with Roche, for its monoclonal antibody treeatment, casirivimab and imdevimab [Ronapreve], for treating COVID-19.

Monoclonal antibodies mimic the natural antibodies that the immune system makes to fight disease. Ronapreve is currently being assessed by Medsafe.

Commenting on the announcement, Pharmac's Chief Executive, Sarah Fitt, said that "while getting vaccinated is by far and away the best line of defence against COVID-19, it's good to know New Zealand will have another treatment available for those who do become unwell".

Pharmaceutical Management Agency (PHARMAC). Pharmac negotiates deal for a further COVID-19 treatment. Internet Document : 2 Nov 2021. Available from: URL: https://pharmac.govt.nz/news-and-resources/news/2021-10-31-pharmac-negotiates-deal-for-a-further-covid-19-treatment/ 